\title{
Population of Xanthomonas oryzae and Concentration of Techlofthalam in Guttation Droplets on Rice Leaf Sprayed with Techlofthalam
}

\author{
Kazuto Nakagami, Harukazu Tanaka, Katashi Yamaoka \\ and Yasuhiro Tsujino \\ Agricultural Chemicals Research Laboratories, \\ Sankyo Co., Ltd., Yasu, Shiga 520-23, Japan
}

(Received April 10, 1980)

\begin{abstract}
Change in population of Xanthomonas oryzae and the concentration of techlofthalam in a guttation droplet on rice leaves sprayed with techlofthalam [N-(2,3-dichlorophenyl)3,4,5,6-tetrachlorophthalamic acid] at a concentration of $100 \mathrm{ppm}$ were examined. Bacterial population in the guttation droplet lowered when the percent of lesion area on the leaf decreased. The concentration of techlofthalam detected was $0.1 \mathrm{ppm}$ or below, with the exception of one sample 1 day after spraying.
\end{abstract}

\section{INTRODUCTION}

Xanthomonas oryzae, the causal organism of widespread bacterial leaf blight in the rice plant, is exuded with vessel fluid from a diseased leaf and exists temporarily in a guttation droplet on the hydathode. This organism plays an important part as an inoculum of secondary infection. ${ }^{1,2)}$ As is necessary for the infection, the bacteria in guttation droplets are at a high population level and have much aggressiveness. We reported in a previous paper $^{3)}$ that a foliar spray with techlofthalam $[N-(2,3$-dichlorophenyl $)-3,4,5,6$ tetrachlorophthalamic acid], an agent for rice bacterial leaf blight control, ${ }^{4,5}$ decreased the population and the multiplication capacity of the bacteria in rice leaf. This study was conducted to determine the change of bacterial population and the concentration of techlofthalam in guttation droplets on rice leaf after foliar sprays with techlofthalam at a concentration of $100 \mathrm{ppm}$.

\section{MATERIALS AND METHODS}

Guttation droplets were periodically collected early in the morning from flag leaves of rice plants (Cultivar, Kinmaze) in a paddy field which had been inoculated by atomizing with a streptomycin-resistant strain of an isolate $\mathrm{H}-5809$ and sprayed uniformly with techlofthalam at $100 \mathrm{ppm}$ after lesion formation. Each sample was filtrated with double layers of cheese cloth, and then the population of viable bacteria was determined according to the method described. ${ }^{3)}$ One part of each sample was stored in a freezing box for quantitative analysis of techlofthalam.

The analytical method was as follows: techlofthalam in the guttation droplets was extracted with ethylacetate. After removal of ethylacetate in the extract with a rotary evaporator, the residue was chromatographed on a mixture of silicagel No. III and celite $545(3: 1, \mathrm{w} / \mathrm{w})$ to remove interfering substances in gas-chromatographic analysis. Techlofthalam was eluted with a mixture of acetone and ethanol $(1: 1, \mathrm{v} / \mathrm{v})$; the eluate was concentrated to dryness. Techlofthalam in the residue was converted to $N$-(2,3-dichlorophenyl)-3, 4, 5, 6-tetrachlorophthalimide by heating in the presence of acetic anhydride. Then the imide was cleaned up by the same silicagel column chromatography as described 
Table 1 Changes of population of viable Xanthomonas oryzae and of concentration of techlofthalam in guttation droplets on the flag leaf of rice plant sprayed with techlofthalam at $100 \mathrm{ppm}$.

\begin{tabular}{|c|c|c|c|c|c|}
\hline \multirow{2}{*}{$\begin{array}{l}\text { Days after } \\
\text { the first } \\
\text { spray }\end{array}$} & \multicolumn{2}{|c|}{$\%$ lesion area of flag leaf } & \multicolumn{2}{|c|}{$\begin{array}{l}\text { Bacterial population } \\
\left(\log _{10} / \mathrm{ml}\right)\end{array}$} & \multirow{2}{*}{$\begin{array}{l}\text { Concentration } \\
\text { of techlofthalam } \\
(\mathrm{ppm})\end{array}$} \\
\hline & Sprayed & Unsprayed & Sprayed & Unsprayed & \\
\hline 0 & 6.8 & 5.8 & - & - & - \\
\hline 1 & -c) & - & 5.7 & 5.5 & 4.96 \\
\hline 3 & - & 一 & 6.8 & 6.7 & 0.09 \\
\hline $6^{b)}$ & 9.0 & 9.7 & 7.2 & 7.4 & 0.10 \\
\hline 11 & - & - & 10.5 & 10.5 & 0.12 \\
\hline 14 & - & - & 6.9 & 6.6 & 一 \\
\hline 16 & $9 \cdot 5^{* * d)}$ & 15.2 & 6.9 & 8.1 & 0.02 \\
\hline 22 & - & - & 6.6 & 9.9 & - \\
\hline 23 & $9.3^{* *}$ & 18.5 & 5.4 & 5.8 & - \\
\hline
\end{tabular}

a) The second spray was made 6 days after the first.

b) The sample was taken prior to the second spray.

c) Not measured.

d) Significantly lower than the respective unsprayed control at $99 \%$ confidence level.

above using a mixture of acetone and $n$ hexane $(5: 95, \mathrm{v} / \mathrm{v})$ as an eluting solvent. The imide was determined by ECD-gaschromatography.

\section{RESULTS AND DISCUSSION}

The result is shown in Table 1 . It was initially observed 16 days after the first spray that lesion development was significantly inhibited by the spray with techlofthalam. Until 11 days after spraying there was no difference between sprayed and unsprayed leaves in the population of viable bacterial cells in the guttation droplet. However, 16 and 22 days after spraying, a much lower population was found on the guttation droplet on the sprayed leaf than on the droplet on the unsprayed. From this result and the previous one, ${ }^{3)}$ it is suggested that sprays with techlofthalam do not increase the amount of bacteria emanating from a diseased leaf but, rather, decrease it. These results also suggest that guttation droplets containing the bacterial cells on the sprayed leaf can bring about less infestation than those on the unsprayed and their less because of the lower population of the bacteria aggressive tendencies.

Techlofthalam detected in the guttation droplet was approximately $0.1 \mathrm{ppm}$ or below, with the exception of one sample 1 day after spraying. A higher concentration in the sample 1 day after spraying appeared to come from dissolution of techlofthalam into the droplet which was deposited on the hydathode, since techlofthalam has the solubility of approximately $14 \mathrm{ppm}$ in distilled water at $25^{\circ} \mathrm{C}$. It is presumed from Table 1 that techlofthalam in the vessels of rice leaf, in which $X$. oryzae multiplies, may exist at a concentration of about $0.1 \mathrm{ppm}$ for at least 10 days following the first spray under the conditions of this study. To clarify a mode of action of techlofthalam, it may be necessary to study in detail the its effect at a concentration of about 0.1 $\mathrm{ppm}$ on the multiplication rate of bacteria, considering the gradual decrease of bacterial population in rice leaf within a few days after spraying. ${ }^{3)}$

The decrease of the techlofthalam concentration in the guttation droplet 1 to 3 days after spraying was striking. The former concentration was 55 times higher than the latter. This suggests a possibility that the guttating rice plants, when dried slowly, permit techlofthalam dissolved in the guttation droplet to enter through the hydathode, though a few evidences of the systemic activity of techlofthalam have been reported. ${ }^{4-6)}$ In the same way, bacterial cells are allowed to enter the hydathode, resulting in symptom production. 


\section{REFERENCES}

1) Y. Mizukami: Shokubutsu Boeki 14, 339 (1960)

2) S. Yoshimura: Bull. Hokuriku Agric. Exp. Stn. 5, 27 (1963)

3) K. Nakagami \& H. Tanaka: J. Pesticide Sci. 5, 511 (1980)

4) K. Nakagami, H. Tanaka, M. Ishida, M. Koremura, T. Honda \& T. Yamazaki: J. Pesticide Sci. 5, 237 (1980)

5) K. Nakagami \& H. Tanaka: J. Pesticide Sci. 5, 243 (1980)

6) M. Yamada, O. Horino, M. Iwano, T. Ando, A. Takisawa, E. J. Lee \& K. Yamada: Exp. Results on Plant Disease in 1973, Hokuriku Agric. Exp. Stn. p. 105, 1974
要 約

\section{テクロフサラムを散布したイネの葉溢液に存} 在する白葉枯病菌密度とテクロフサラムの濃

度

中神和人, 田中治一, 山岡 剛, 辻野泰宏 イネ白葉枯病防除䯇テクロフサラムを $100 \mathrm{ppm}$ (有勃 成分) でイネに散布して，葉溢液中の白葉枯病菌密度と テクロフサラム濃度を経時的に調査した．散布イネから 採取した葉溢液中の菌密度は, 葉の病斑拡大が抑制され た時期には，無散布イネのそれよりも明らかに低かっ た. テクロフサラムの濃度は, 葉の排水組織に付着した テクロフサラムが溶解したと推定される散布 1 日後の試 料を除くと，約 $0.1 \mathrm{ppm}$ あるいはそれ以下であった。 